\title{
The Differences of Prevalence and Risk Factors of Asthma in Children with Aged 6-7 Years and 13-14 Years Based on Questionnaire of International Study of Asthma and Allergies in Childhood (ISAAC) in Padang City
}

\author{
Finny Fitry Yani ${ }^{1}$, Eryati Darwin ${ }^{2}$, Rusdi $^{1}$, Fitrisia Amelin ${ }^{3}$ \\ \{finny_fy@yahoo.com ${ }^{1}$ \} \\ Department of Child Health, Faculty of Medicine, Universitas Andalas / Dr. M Djamil General \\ Hospital, Padang, Indonesia ${ }^{1,3}$ \\ Department of Histology Faculty of Medicine, Universitas Andalas, Padang, Indonesia ${ }^{2}$
}

\begin{abstract}
Prevalence of asthma increased especially in children in the urban city regarding increasing air pollution, such as Padang city. There were two differences age groups affected by asthma, aged 6-7 years and 13-14 years based on International Study of Asthma and Allergies in Childhood (ISAAC) and performed in 2008 in Padang City. This study aimed to find any increasing asthma prevalence in two age group of children. A crosssectional study conducting at several elementary schools (6-7 years) and junior high school (13-14 years) in Padang during August-November 2016 by cluster sampling. We used a questionnaire of ISAAC to determine asthma. About 822 subjects were recruited. The asthma prevalence on age 6-7 years and 13-14 years were about $12.97 \%$ and $9.5 \%$, respectively. At least one of parents subjects in both age groups have an atopic history only in mother about $11.72 \%$ and only in father about $9.73 \%$. The prevalence of asthma in Padang was $11,19 \%$, and atopy is a significant risk factor for developing asthma.
\end{abstract}

Keywords: Asthma, Elementary and Junior High Schools, Atopy, ISAAC.

\section{Introduction}

Asthma is a chronic disease affected by limitation of airway flow regarding chronic inflammation. Many studies found that the prevalence of asthma increased in children and adults was estimated to $7.2 \%$ (6\% in adults and $10 \%$ in children) $4,5 \%$ [1], [2], [3]

ISAAC developed since 1989 other allergic disease allergic rhinitis and atopic dermatitis. The results of the study by ISAAC methods can describe the prevalence and severity of asthma among country [5], [6]. ISAAC using a standard questionnaire and conducted on two age groups; they are 13-14 years and 6-7 years. Age 13-14 years old represents periods of frequent deaths from asthma and 6-7 years old represent the beginning where the prevalence of asthma tends to be high [6].

Padang is a city that has developed into an urban city in the last 10 years, which led to increased pollution levels along with lifestyle changes into urban style, particularly of food consumption. This situation is a risk factor for the development of asthma, so the potential for 
an increase in the prevalence asthma [7]. This study aimed to determine the prevalence of asthma in children in the city of Padang.

\section{Method}

\subsection{Research design}

This study was survey research with cross-sectional design conducted at several elementary schools and Junior High School in Padang during August -November 2016. Ethics approval was obtained from the Ethics Committee of the Faculty of Medicine, Andalas University.

\subsection{Population and Sample}

The population was children aged 6-7 years who were at $1^{\text {st }}$ grade and $2^{\text {nd }}$ grade of elementary school and with their parents and children aged 13-14 years who were at $1^{\text {st }}$ grade and $2^{\text {nd }}$ grade of junior high school. The minimum number of samples needed was as 380 people from every age group so that the minimum total sample was 760 people. Sample selected to begin with cluster method and continued with simple random sampling method for school elections.

\subsection{ISAAC Questionnaire}

This study used a core questionnaire for asthma (ISAAC phase 1) and a questionnaire for a risk factor (ISAAC phase 2) which has been validated before. Selected and trained 10 people enumerators was helping filling out the questionnaire by respondents.

\subsection{Operational Definition}

Asthma is characterized by the presence of wheezing in the last 12 months. ISAAC questionnaire is a questionnaire used in the International Study of Asthma and Allergies in Childhood (ISAAC), consisting of 30 questions, which contain data on the incidence of asthma, family history, and environment factor [4].

\subsection{Data Collection Procedures}

For legalization, the implementation of research on this student population of the school has been approved by the Head of Education Department of Padang. Through cooperation and communication with the Principal, parents of elementary school students were inviting, and the meeting was held to explain and fill out the questionnaires, while for junior high school student was scheduled without parents.

On the schedule, all the research subject were explained asthma in general and accompanied by a community of informed consent. The questionnaire distributed to parents subject (elementary school students) and subject (junior high school) and filling out the questionnaires was carried out directly assisted by trained enumerators. Explanations on the subject of junior high school group is also assisted by ISAAC video about asthma. If there were respondents who are illiterate will be guided in particular. 


\subsection{Data Analysis}

To determine the relationship between variables used Chi-Square test with bivariate analysis and for multivariate analysis used logistic regression. All the necessary data is recorded, then processed using SPSS and presented in the form of tables and figures.

\section{Result}

Research conducted in 16 schools made up of 15 elementary and 4 junior high school includes 822 subjects, 401 subjects $(48.8 \%)$ were children aged 6-7 years old and 421 subjects (51.2\%) were children aged 13-14 years old. Questionnaires for elementary school students filled out by parents while the junior high school student questionnaires filled out by themselves. Seventy-three people drop out because they do not fill out the questionnaire completely.

Table 1. School Name and number of each sample

\begin{tabular}{llll}
\hline No. & School name & $\begin{array}{l}\text { Questionnaires were filled } \\
\mathrm{f}(\%)\end{array}$ & $\begin{array}{l}\text { Asthma }(+) \\
\mathrm{f}(\%)\end{array}$ \\
\hline 1. & SDN 03 Ikur Koto & $34(8.48)$ & $7(13.46)$ \\
\hline 2. & SDN 03 Purus & $14(3.50)$ & $4(7.69)$ \\
\hline 3. & SDN 04 Purus & $21(5.24)$ & $2(3.85)$ \\
\hline 4. & SDN 07 Ikur Koto & $29(7.23)$ & $1(1.18)$ \\
\hline 5. & SDN 13 Ikur Koto & $28(6.98)$ & $3(1.92)$ \\
\hline 6. & SDN 13 Purus & $21(5.24)$ & $2(3.85)$ \\
\hline 7. & SDN 13 Damar & $9(2.24)$ & $0(0)$ \\
\hline 8. & SDN 04 Damar & $7(1.74)$ & $1(1.18)$ \\
\hline 9. & SDN 16 Surau Gadang & $13(3.24)$ & $4(7.69)$ \\
\hline 10 & SDN 16 Siteba & $37(9.23)$ & $4(15.38)$ \\
\hline 11. & SDN 17 Koto Baru & $41(10.22)$ & $0(0)$ \\
\hline 12. & SDN 21 Purus & $15(3.74)$ & $6(11.54)$ \\
\hline 13. & SDN 30 Cengkeh & $46(11.47)$ & $6(11.54)$ \\
\hline 14. & SDN 36 Cengkeh & $56(13.97)$ & $4(7.69)$ \\
\hline 15. & SDIT Ridhotullah & $30(7.48)$ & $11(27.50)$ \\
\hline 16. & SMP 2 Padang & $124(10.8)$ & $11(27.50)$ \\
\hline 17. & SMPN 16 Padang & $125(15.21)$ & $17(42.50)$ \\
\hline 18. & SMPN 17 Padang & $132(16.05)$ & $1(2.50)$ \\
\hline 19. & SMP PGAI Padang & $40(48.7)$ & $92(100)$ \\
\hline & Total & $822(100)$ &
\end{tabular}




\subsection{Basic Characteristics of Research Subjects}

Table 2. Basic Characteristics of Research Subjects

\begin{tabular}{|c|c|c|}
\hline \multirow{2}{*}{ Characteristic } & 6-7 years old & $13-14$ years old \\
\hline & $f(\%)$ & $\mathrm{f}(\%)$ \\
\hline \multicolumn{3}{|l|}{ Gender } \\
\hline Boys & $185(46.1)$ & $186(44.18)$ \\
\hline Girls & $216(53.9)$ & $235(55.82)$ \\
\hline \multicolumn{3}{|l|}{ Nutritional status } \\
\hline Very Thin & $24(6)$ & $11(2.61)$ \\
\hline Thin & $36(9)$ & $18(4.28)$ \\
\hline Normal & $299(75)$ & $326(77.43)$ \\
\hline Fat & $16(4)$ & $37(8.79)$ \\
\hline Obesity & $23(6)$ & $29(6.89)$ \\
\hline \multicolumn{3}{|l|}{ Parent's education } \\
\hline \multicolumn{3}{|l|}{ Father } \\
\hline Low & $124(30.92)$ & $106(25.18)$ \\
\hline Secondary & $225(56.11)$ & $246(58.43)$ \\
\hline High & $52(12.97)$ & 69 (16.39) \\
\hline \multicolumn{3}{|l|}{ Mother } \\
\hline Low & $110(27.4)$ & $103(24.47)$ \\
\hline Secondary & $229(57.1)$ & $243(57.72)$ \\
\hline High & $62(15.5)$ & $75(17.81)$ \\
\hline \multicolumn{3}{|l|}{ Parent's job } \\
\hline \multicolumn{3}{|l|}{ Father } \\
\hline Work & $382(95.3)$ & 345 (82) \\
\hline Doesn't Work & $19(4.7)$ & $76(18)$ \\
\hline \multicolumn{3}{|l|}{ Mother } \\
\hline Work & $67(16.71)$ & 63 (14.96) \\
\hline Doesn't Work & $334(83.29)$ & $358(85.04)$ \\
\hline \multicolumn{3}{|l|}{ Economic status } \\
\hline By the UMR & $180(44.89)$ & 47 (11.16) \\
\hline Not suitable UMR & $221(55.11)$ & $374(88.84)$ \\
\hline \multicolumn{3}{|l|}{ Number of siblings } \\
\hline $2 \leq$ & $282(70.32)$ & $360(85.5)$ \\
\hline$>2$ & $119(29.68)$ & $61(14.5)$ \\
\hline Total & $401(100)$ & $421(100)$ \\
\hline
\end{tabular}

Table 1 shows that characteristic from subject aged 6-7 years old, from 401 subjects who follow the study, there were 216 girls $(53.9 \%) ; 299$ subjects had normal nutritional status $(75 \%) ; 225$ subjects with secondary educated father $(56.11 \%) ; 229$ subjects with secondarily educated mothers (57.1\%); 38.2 subject's father had a job (95.3\%); 334 subject's mothers did not work (83.29\%); 221 subjects came from families whose income didn't comply with the minimum wage $(55.11 \%)$; and 282 subjects had siblings less than or equal to two $(70.32 \%)$.

Characteristic from subjects aged 13-14 years old, from 421 subjects who follow the study, there were 235 girls $(55.82 \%) ; 326$ subjects had normal nutritional status $(77.43 \%) ; 315$ subjects with father educated upper middle or high school, etc. (74.82\%); 318 subjects with mother educated upper middle or high school, etc. $(75,53 \%) ; 345$ subjects with the father of private sector workers $(82 \%) ; 374$ subjects whose mothers did not work $(85,0.4 \%)$; 374 students 
came from families whose income did not comply with the minimum wage $(88,84 \%)$; and 360 subjects who had siblings less than 2 people $(85,5 \%)$.

\subsection{Characteristics of Asthma Symptoms of the Research Subject}

Table 3. Characteristic of Asthma Symptoms of the Subject Research

\begin{tabular}{lcc}
\hline \multicolumn{1}{c}{$\begin{array}{c}\text { Characteristic of Asthma } \\
\text { Symptom }\end{array}$} & 6-7 years old & 13-14 years old \\
\cline { 2 - 3 } & $\mathrm{f}(\%)$ & $\mathrm{f}(\%)$ \\
\hline Wheezing & $38(73.08)$ & $32(80.0)$ \\
History of Asthma & $20(38.46)$ & $20(50.0)$ \\
Wheezing after Activity & $14(26.92)$ & $24(60.0)$ \\
Dry Cough at Night & $35(67.31)$ & $22(55.0)$ \\
\hline Total & $52(100)$ & $40(100)$ \\
\hline
\end{tabular}

Table 3 shows that among 52 subjects aged 6-7 years old who had asthma, the most common symptom was wheezing as many as 38 subjects (73.08\%) and for subjects aged 13-14 years old, among 40 subjects with asthma, the most common symptom was wheezing as many as 32 subjects $(80.0 \%)$

\subsection{History of the Atopy in Parents of the Research Subject}

Table 4. History of the Atopy in Parents of the Research Subject

\begin{tabular}{lcc}
\hline \multirow{2}{*}{ History of Atopy in Parents } & $6-7$ years old & $13-14$ years old \\
\cline { 2 - 3 } & $\mathrm{f}(\%)$ & $\mathrm{f}(\%)$ \\
\hline Mothers & $18(34.52)$ & $7(17.5)$ \\
Fathers & $4(7.69)$ & $6(15.0)$ \\
Both & $5(9.62)$ & $2(5.0)$ \\
Don't have a history of atopy & $25(48.08)$ & $25(62.5)$ \\
\hline Total & $52(100)$ & $40(100)$ \\
\hline
\end{tabular}

Table 4 revealed that history of atopy in parents of subjects aged 6-7 years old, most of the subjects had one atopy factor that was maternal atopy as many as 18 subjects $(34.52 \%)$ and atopy factor from father as many as 4 subjects (7.69\%). There are 5 subjects which both parents had atopy factor. On aged 13-14 years, subjects revealed that most subject also only had one atopy factor that was maternal atopy as many as 7 subjects (17.5\%) and atopy factor from father as many as 6 subjects (15.0\%). There are also 2 subjects which both parents had atopy factor. 


\subsection{Prevalence of Asthma}

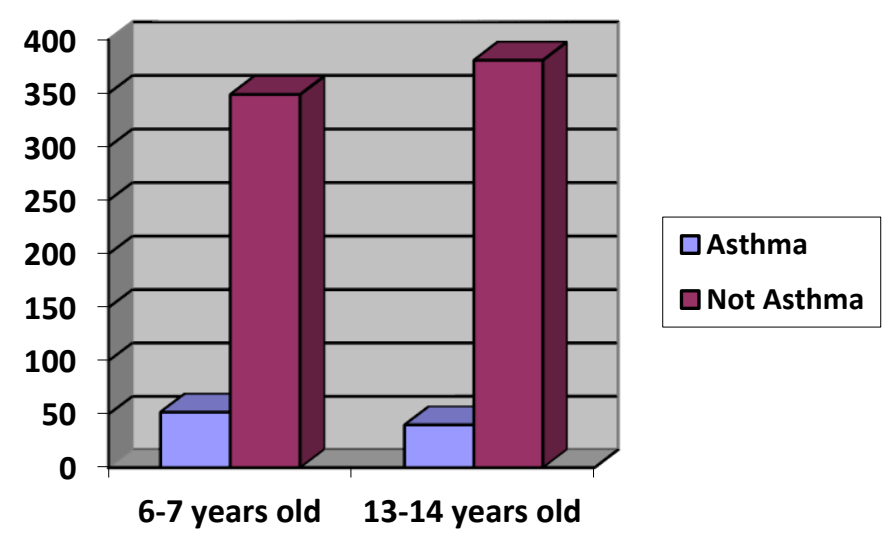

Fig. 1. Prevalence of Asthma obtained by questionnaire ISAAC

The study shows based questionnaires ISAAC asthma prevalence in children aged 6-7 years old was 52 subjects (12.97\%) and for children aged 13-14 years old was 40 subjects $(9.5 \%)$.

\section{Discussion}

\subsection{Research on subject aged 6-7 years old}

In this study, the most common symptom experienced by subjects aged 6-7 years old was wheezing $(73.08 \%)$. While the percentage for other symptoms such as; history of asthma (38.46\%), wheezing after exercise $(26.92 \%)$ and dry cough at night $(67.31 \%)$. A worldwide study also found that the most common symptom of asthma in children aged 6-7 years in Asia Pacific Region was a dry cough at night which was as much as $20.6 \%$. [8]. The same results also found in studied in children aged 6-7 years old that conducted by Lima and friends in Sao Paolo, that the most common symptom of asthma that they have found was a dry cough at night which was as much as 37.9\%. [9] This difference may be due to the prevalence of symptoms of asthma affected by region. [8]

The influence of genetic factors on the incidence of asthma was identified through their history of atopy, like asthma, allergic rhinitis, and eczema in older people. In this study showed that most parent's subject only had one atopy factor that was $34.52 \%$ from mother and $7.69 \%$ from father. Based research that conducted by Afdal et al., atopy factor from mother or father is a significant factor for the onset of asthma ( $\mathrm{p}<0.05$ ), but atopy factor from both parents statistically not significant for asthma $(\mathrm{p}>0,05)$. [10][11]

History of atopy in father can increase the risk of asthma by 3.18 times, while the history of atopy from mother can increase the risk of asthma by 5.2 times. Maternal genetic influences are stronger than father genetic in the event of asthma. About $80 \%$ children who have asthma have atopy factors, and $60 \%$ of children are at risk of suffering from atopy if both parents have atopy history, and if only one parent has atopy history, then the chances of the child becoming atopy are around 40\%. [10][12] 


\subsection{Research on subject aged 13-14 years old}

Based on the ISAAC questionnaire, the most common symptoms experienced by subject aged 13-14 years old was wheezing $(80.0 \%)$. Other symptoms experienced by students with a percentage as follows; history of asthma (50.0\%), wheezing after exercise $(60.0 \%)$, and dry cough at night $(55.0 \%)$. While the research conducted by Yunus et al. in junior high school students in East Jakarta in 2001, obtained $7.20 \%$ of students have a history of wheezing, $4.1 \%$ had to wheeze in the last 12 months, $1.8 \%$ had experienced severe asthma attacks in 12 Last month, 3.3\% had wheezing after exercise, and $6.3 \%$ had a cough at night. As well as studied on children aged 6-7 years old, studied on children aged 13-14 years old that conducted worldwide also found that the most common symptom of asthma that has been found was a dry cough at night and for Asia Pacific region its reached $20.6 \%$ [8], [13],[14].

From this study showed that most parent's subjects only had one atopy factor, that was $17.5 \%$ from mother and $15.0 \%$ from father. Atopy is a significant risk factor for developing asthma, approximately $85 \%$ of children with asthma and $40-50 \%$ of an adult with asthma newonset have an allergic response to aeroallergens. However, environmental factors also play an important role in the pathogenesis of asthma. Someone who has atopy, the symptoms will appear if there are environmental factors that can induce pro atopies gene expression, such as the presence of pollutants, dust, or flower pollen. Exposure of dogs is another risk factor for asthma in adolescence. [15][16]

\subsection{Prevalence of Asthma}

Diagnosis of asthma was based on the symptoms of wheezing in the last 12 months. The prevalence of asthma in subject aged 6-7 years old was 12.97\% and subject aged 13-14 years old was 9.5\%. Based on research conducted by Afdal et al. in Padang in 2009, the prevalence of asthma at the age of 6-7 years of the subject by ISAAC questionnaire that is equal to 8\% [8]. While the prevalence of subject aged 13-14 years old in East Jakarta in 2001, was 8.9\% [12]. In global, current asthma prevalence in children aged 6-7 years was $11.7 \%$ and about $14.1 \%$ in children aged 13-14 years old. [17]

Based on The Global Asthma Report 2014, through a survey using ISAAC questionnaire in 798.685 children aged 13-14 years in 233 centers in 97 countries, showed the prevalence of asthma in the world by $14 \%$. The highest prevalence (> 20\%) were found in Latin American countries, Europe, North America, and South Africa. While the lowest prevalence $(<5 \%)$ is found in India, Asia Pacific, Eastern Mediterranean, Northern Europe, and Earthen Europe [14]. In Indonesia, asthma is one of the causes of morbidity after infection. The prevalence of asthma in children is varied, with a range of 2.1 until $22.2 \%$ in some major cities in Indonesia [15], [18].

\section{Conclusion}

The prevalence of asthma in Padang was 11,19\%, and atopy in one parent is a risk factor for developing asthma. Further study with a large sample of asthma is required to analyze the factor that contributing to asthma in children. 


\section{References}

[1] Smyth, RL.: Asthma: A major pediatric health issue. Resper Res;3 suppl.1:S3-7 (2002)

[2] Kartasasmita, CB.: Epidemiologi asma anak. Dalam: Rahajoe NN, Supriyatno B, Setyanto DB, penyunting. Buku Ajar Respirologi Anak. Edisi pertama, pp. 71-84. Jakarta: Badan Penerbit IDAI, Indonesia (2008)

[3] Pusat Data dan Informasi Kementerian KEsehatan RI. You can control your asthma.

[4] ISAAC Steering Committee.: Worldwide variations in prevalence of asthma symptoms: the international study of asthma and allergies in childhood (ISAAC). Eur Respir J. Vol 12. pp. 31535 (1998).

[5] Neto HJC, Rosario NA, Sole D, Latin American ISAAC Group.: Asthma and rhinitis in South America: How different they are from other parts of the world. Allergy Asthma Immunol Res. 4(2). pp. 62-7 (2012)

[6] Asher MI, Weiland K.: The International study of asthma and allergies in childhood (ISAAC). clinical and experimental allergy. Vol.2 (5). pp. 52-66 (1998).

[7] Mangguang, M.: Faktor risiko kejadian asma pada anak di Kota Padang. Arc. Com. Health. Vol.3 No.1. pp. 1-7 (2016).

[8] Pearce N, Ait-Khlaed N, Richard B, Mallol J. Keil U, Mitchell E, et al.: worldwide trends in the prevanlence of asthma symptoms: phase III of the International Study of Asthma and Allergis in Childhood (ISAAC). Thorax; 62. pp. 757-65 (2007)

[9] Lima RG, Pastorino AC, Casagrunde RRD, Sole D, Leone C, Jacob CMA.: Prevalence of asthma, rhinitis, eczema in 6-7 years old student from the western districts od Sao Paulo City, using the standardized questionnaire of the International Study of Asthma and Allergies in Childhood (ISAAC)-phase IIIB. Clinics;62(3). pp. 225-34 (2007)

[10] Afdal, Yani FF, Basir D, Machmoed R.: Faktor risiko asma pada murid sekolah dasar usia 6-7 tahun di Kota Padang. Jurnal Kesehatan Andalas;1(3). pp. 118-24 (2011).

[11] Rahajoe N, Supriyatno B, Setyanto DB.: Pedoman nasional asma anak. pp. 1-44. Jakarta: UKK Pulmonologi, Indonesia. (2012).

[12] Von Mutius E, Nocolai T.: Familial aggregation of asthma in a South Bavarian population. Am J Respir Crit Care Med;153. pp. 1266-72 (1996).

[13] Yunus F, Antaria R, Rasmin M, Mangunnegoro H, Jusuf A, Bachtiar A.: Asthma prevalence among high school students in east Jakarta, 2001, based on ISAAC questionnaire. Med J Indones. Vol 12, No 3. pp. 179-85 (2003).

[14] Paul G, Brehm JM, Alcorn JF, Holguin F, Aujla SJ.: Vitamin D and asthma. Am J Respir Crit Care Med;185(2). pp. 124-32.

[15] Peden DB.: Development of atopy and asthma: Candidate enviromental influences and important periods of exposure. Enviromental Factors in Development of Atopy, 108(3). pp. 475-81 (2000).

[16] Masoli M, Fabian D, Holt S, Beasley R.: Global initiative for asthma (GINA) program. The global burden of asthma: executive summary of the GINA Dissemination Committee report. Allergy. Vol. 59, pp. 469-78 (2004).

[17] Sole D, Camelo-Nunes IC, Wandalsen GF, Mallozi MC.: Asthma in children and adolescents in Brazil : constribution of the International Study of Asthma and Allergies in Childhood (ISAAC). Rev Paul Pediatr;32(1) pp. 14-26 (2014).

[18] The Global Asthma Report 2014. Diakses dari http://globalasthmareport.orgom http://globalasthmareport.org (2014). 